\title{
Carga proviral do HTLV-1 e HTLV-2: um método simples através da PCR quantitativa em tempo real
}

\author{
HTLV-1 and HTLV-2 proviral load: a simple method using \\ quantitative real-time PCR
}

\author{
Bruna Pedroso Tamegão-Lopes ${ }^{1}$, Priscila Rocha Rezende ${ }^{1}$, Luciana Maria Cunha \\ Maradei-Pereira ${ }^{1}$ e José Alexandre Rodrigues de Lemos ${ }^{1,2}$
}

\begin{abstract}
RESUMO
Os vírus linfotrópicos de células Thumanas, quando integrados ao genoma da célula hospedeira, provírus, têm como marcador de replicação seu DNA proviral. A carga proviral parece ser um importante fator no desenvolvimento de patologias associadas a estes retrovírus. Neste estudo foi desenvolvida uma metodologia para quantificação absoluta da carga proviral dos HTLV-1 e HTLV-2 através da PCR em tempo real. Cinqüenta e três amostras de doadores de sangue com teste de ELISA reagente foram submetidas à metodologia, que utilizou o sistema TaqMan ${ }^{\circledR}$ para três seqüências alvo: HTLV-1, HTLV-2 e albumina. A quantificação proviral absoluta foi determinada através da proporção relativa entre o genoma do HTLV e o genoma da célula hospedeira, levando em consideração o número de leucócitos. O método apresentado é sensível (215 cópias/mL), prático e simples para quantificação proviral, além de eficiente e adequado para confirmação e discriminação da infecção pelos tipos virais.
\end{abstract}

Palavras-chaves: HTLV. PCR quantitativa em tempo real. Carga proviral do HTLV.

\begin{abstract}
When the human T cell lymphotropic virus (HTLV) is integrated with the host cell genome (provirus), its proviral DNA is a replication marker. Proviral load appears to be an important factor in the development of diseases related to these retroviruses. In this study, a methodology for absolute quantification of the HTLV-1 and HTLV-2 proviral load using real-time PCR was developed. Fifty-three blood donor samples with positive ELISA test result were subjected to this methodology, which utilized the TaqMan ${ }^{\circledR}$ system for three target sequences: HTLV-1, HTLV-2 and albumin. The absolute proviral load was quantified using the relative ratio between the HTLV genome and the host cell genome, taking into consideration the white blood cell count. The method presented is sensitive (215 copies/ml), practical and simple for proviral quantification, and is efficient and appropriate for confirming and discriminating infections according to viral type.
\end{abstract}

Key-words: HTLV. Quantitative real-time PCR. HTLV proviral load.

Os vírus linfotrópicos de células T humanas (HTLV-1 e HTLV-2) integram a família Retroviridae, subfamília Oncovirinae, gênero Deltaretrovirus. Estes retrovírus têm sido classificados na família Retroviridae, baseados em seqüências genéticas e homologias estruturais ${ }^{5}$, caracterizando-se por serem os únicos vírus diplóides de polaridade positiva ${ }^{2}$. Estes vírus infectam linfócitos, sendo o HTLV-1 com preferência por células $\mathrm{CD}^{+}$e o HTLV-2 por células $\mathrm{CD}^{+}$, ambos com a capacidade de se integrar no genoma da célula hospedeira passando a se chamar de provírus.

São transmitidos verticalmente ${ }^{1928}$ e horizontalmente, através de contato sexual, transfusão sanguínea e/ou uso de drogas intravenosas ${ }^{171522}$. A transmissão hematogênica tem sido considerada relevante na disseminação do HTLV-1 e do HTLV-2 em áreas urbanas, entre UDI (usuários de drogas injetáveis) e doadores de sangue ${ }^{730}$. Entretanto, estima-se que

1. Divisão de Biologia Celular e Molecular da Fundação HEMOPA, Belém, PA, Brasil. 2. Departamento de Genética da Universidade Federal do Pará, Belém, PA, Brasil.

Endereço para correspondência: Dr. José Alexandre Rodrigues de Lemos. Laboratório de Biologia Molecular/Fundação HEMOPA. Travessa Padre Eutíquio 2901, 66033-000 Belém, PA, Brasil.

Tel: 5591 3242-9100, ramal: 244; Fax: $55913211-5435$

e-mail: lemos@ufpa.br

Recebido para publicação em 29/8/2005

Aceito em 4/12/2006 
a transmissão viral por transfusão ocorra em baixos, mas significativos níveis $^{329}$.

As principais patologias associadas à infecção pelo HTLV1 são: paraparesia espástica tropical/mielopatia associada ao HTLV-1 (PET/MAH) ${ }^{9} 2634$; linfoma/leucemia de células T do adulto (LLcTA) ${ }^{1632}$; uveíte associada ao HTLV-1 (HU) ${ }^{23}$; além de outras manifestações como dermatite infecciosa $a^{27}$. No Brasil, todas as patologias relacionadas à infecção pelo HTLV-1 já foram descritas em indivíduos infectados.

Em Hemocentros e Serviços de Hemoterapia, a implantação de testes de triagem sorológica para HTLV-1 e para HTLV-2 fez-se em cumprimento à portaria do Ministério da Saúde, de número 1376, de 19 de novembro de 1993. De maneira que se tornou possível identificar doadores infectados que necessitavam de orientação e acompanhamento, além de impedir que estes agentes virais fossem transmitidos através de transfusão em procedimentos hemoterápicos que empregam componentes celulares.

O diagnóstico sorológico da infecção pelos HTLV é baseado na presença de anticorpos, anti-HTLV, no soro do indivíduo. Entretanto, esta técnica é limitada na verificação da infecção em alguns aspectos, como por exemplo, quando o indivíduo infectado encontra-se no período de janela imunológica da infecção ou, está infectado por variantes imunológicas que não estão incluídas no teste de sorologia ${ }^{4} 1520$.

Holland cols ${ }^{14}$ foram os primeiros a demonstrar que a clivagem de uma sonda duplamente marcada, pela atividade 5' exonuclease da Taq DNA polimerase, poderia ser utilizada para detectar produtos específicos em uma reação de PCR $^{10}{ }^{33}$. Cada sonda é composta de duas moléculas: na extremidade 5' a molécula reporter dye, FAM (6- carboxifluoresceína) e na extremidade 3' a molécula quencher dye, TAMRA (6- carboxitetrametilrodamina).

É a partir da molécula reporter dye que se observa à emissão de fluorescência durante a fase de amplificação da PCR. A molécula quencher dye modula através do princípio de transferência de energia ressonante (FRET), a energia inerente à sonda intacta. Durante cada ciclo da PCR, uma molécula reporter dye é clivada para cada sequiência alvo amplificada, sendo esta fluorescência lida em tempo real ${ }^{614}$.

Nos ciclos iniciais da PCR há pouca mudança na emissão do sinal fluorescente. Isto define a linha base (baseline) do gráfico de amplificação. Qualquer aumento na emissão de fluorescência capaz de ultrapassar a baseline indica a detecção de acúmulos de produtos da PCR. Este parâmetro ou $\mathrm{Ct}$ (cycle threshold) é tido como o número fracionado de ciclos os quais acúmulos de fluorescência ultrapassam o limite fixado ${ }^{12}$.

A detecção da carga proviral através da PCR em tempo real é considerada relevante no monitoramento do número de células sanguiíneas periféricas infectadas e na avaliação da propensão a patologias associadas ao HTLV-1. Alta carga proviral de HTLV-1 em células sanguíneas periféricas tem sido associada com alto risco para doenças neurológicas ${ }^{24}$. No caso do HTLV-2, um número significativo de linfócitos infectados pode contribuir para acelerar a imunodeficiência e aumentar o risco de neuropatia em indivíduos co-infectados com HIV- ${ }^{18}$.

A carga proviral pode servir de ferramenta para monitoramento biológico da eficácia de quimioterápicos e/ ou anti-retrovirais, no caso de pacientes em tratamento da LLcTA $^{6}{ }^{18}$, sendo possível à integração deste método no protocolo de manejo clínico de pacientes infectados por estes vírus ${ }^{832}$. A análise da carga proviral associada a outros fatores, pode atuar como um indicador na predisposição a doenças associadas aos $\mathrm{HTLV}^{81821}$. Em portadores assintomáticos, como doadores de sangue, a carga proviral pode ser um bom indicador de curso da infecção nestes indivíduos.

Este estudo tem como proposta a padronização do método da PCR quantitativa em tempo real para quantificação absoluta da carga proviral do HTLV-1 e do HTLV-2, bem como confirmar e discriminar a infecção por ambos os tipos virais em doadores de sangue com sorologia reagente para HTLV.

\section{MATERIAL E MÉTODOS}

Amostras. Foram analisadas cinqüenta e três amostras $(\mathrm{n}=53)$ de doadores de sangue da Fundação HEMOPA, na Cidade de Belém do Pará, considerados inaptos para o processo de doação, porquanto na etapa de triagem sorológica terem tido resultado reagente no teste de ELISA para HTLV. As amostras de sangue foram coletadas em tubos de $5 \mathrm{ml}$, contendo EDTA (anticoagulante etil-enediaminetetraácido-acético). Todas as amostras foram submetidas à contagem eletrônica de leucócitos, antes da etapa de extração de DNA genômico.

Triagem sorológica. A triagem sorológica utilizou teste ELISA seqüencial, contendo antígenos selecionados que detectam anticorpos IgA, IgM e IgD anti-HTLV (MUREX HTLVI/II - Abbott Divisão de Diagnóstico). 0 teste ELISA foi realizado em duplicata e foram consideradas amostras sorologicamente reagentes, aquelas que exibiram valores de densidade óptica 20\% maior que o valor de cut-off da placa.

Extração de DNA. A extração de DNA genômico foi realizada utilizando o kit de purificação de DNA genômico GFX (Amersham Pharmacia Biotech), a partir de leucócitos do sangue periférico, de acordo com instruções do fabricante.

PCR em tempo real. A PCR em tempo real utilizou o sistema TaqMan ${ }^{\circledR}$ (Applied Biosystems, Foster City, CA) de três seqüências alvo: o gene da albumina, como controle endógeno e as regiões não homólogas do gene pol do HTLV-1 e do HTLV-2. Primers e sondas foram desenhados e sintetizados pelo serviço Assay-by-Design ${ }^{\text {SM }}$ (Part Number 4331348) a partir de sequiências de interesse enviadas à Applied Biosystems. As sequiências de primers e sondas utilizadas na técnica da PCR em tempo real estão descritas nas Tabelas 1 e 2.

As reações da PCR foram preparadas utilizando o conjunto de reagentes TaqMan® Universal PCR Master Mix (Applied 
Tabela 1 - Seqüência nucleotídica de primers utilizados na reação da PCR.

\begin{tabular}{lc}
\hline Primer & Sequiências $\left(5^{\prime}-3{ }^{\prime}\right)$ \\
\hline HTLV-1 F & GAACGCTCTAATGGCATTCTTAAAACC \\
HTLV-1 R & GTGGTTGATTGTCCATAGGGCTAT \\
HTLV-2 F & CAACCCCACCAGCTCAGG \\
HTLV-2 R & GGGAAGGTTAGGACAGTCTAGTAGATA \\
Albumina F & GCTCAACTCCCTATTGCTATCACA \\
Albumina R & GGGCATGACAGGTTTTGCAATATTA \\
\hline
\end{tabular}

Tabela 2 - Seqüiência nucleotídica de sondas utilizadas na reação da PCR.

\begin{tabular}{lc}
\hline Sonda & Seqüências $\left(5^{\prime}-3^{\prime}\right)$ \\
\hline HTLV-1 & FAM-ACAAACCCGACCTACCC-NFQ \\
HTLV-2 & FAM-TCGAGAGAACCAATGGTATAAT-NFQ \\
Albumina & FAM-TTGTGGGCTGTAATCAT-NFQ \\
\hline
\end{tabular}

Biosystems, Foster City, CA), contendo nucleotídeos, tampão, UNG, AmpliTaq ${ }^{\circledR}$, referência passiva (ROX), de acordo com instruções do fabricante. 0 protocolo de reação utilizou $15 \mu \mathrm{L}$ de Master Mix, 10,5 $\mu \mathrm{L}$ de água, 1,5 $\mu \mathrm{L}$ de Assay-by-Design (conjunto de primer e sonda), $3 \mu \mathrm{L}$ de DNA, sendo $30 \mu \mathrm{L} o$ volume final.

Foi utilizada a plataforma ABI PRISM 7000 (Applied Biosystems, Foster City, CA), com o seguinte protocolo de ciclagem: um ciclo de $50^{\circ} \mathrm{C}$ durante 2 minutos; um ciclo de $95^{\circ} \mathrm{C}$ durante 10 minutos; 50 ciclos de $90^{\circ} \mathrm{C}$ durante 50 segundos e $60^{\circ} \mathrm{C}$ durante 1 minuto.

Quantificação proviral absoluta. Para realização da quantificação absoluta, inicialmente, foi realizada uma quantificação relativa, baseada em uma proporção que derivou da relação quantitativa entre alvo e o controle endógeno: Proporção do HTLV-1 ou HTLV-2 integrado no Genoma (PHG):

$$
\frac{2^{\text {-CT Alvo }}}{2^{\text {-CT Albumina }}}
$$

A equação final proposta para quantificação da carga proviral absoluta do HTLV-1 ou HTLV-2, considerou a contagem de leucócitos por $\mathrm{mm}^{3}$ da seguinte forma:

2-CT Alvo

$$
\frac{2^{- \text {CT Albumina }}}{2^{-C T} \text { Leucócitos X } 2}=\text { cópias DNA proviral } / \mathrm{mm}^{3}
$$

0 número "2" representa o par de cromossomos do genoma celular ao qual o HTLV-1 ou o HTLV-2 pode se integrar. Os valores de carga proviral foram expressos em número de cópias de DNA do HTLV-1 ou HTLV-2 integrados no genoma do hospedeiro por $\mathrm{mm}^{3}$ de sangue.

\section{RESULTADOS}

A técnica da PCR em tempo real foi realizada em cinqüenta e três amostras $(\mathrm{n}=53)$ de DNA proviral extraído de leucócitos de sangue periférico, consideradas reagentes no teste de triagem sorológica, com o objetivo de confirmar, discriminar e quantificar a infecção, nestes indivíduos.
Neste estudo, todos os portadores de infecção por HTLV eram assintomáticos.

A média de idade dos doadores inaptos foi de 40,5 anos $(\mathrm{DP} \pm 12,9)$, sendo que dentre estes $18(34 \%)$ pertenciam ao sexo feminino e 35 (66\%) ao sexo masculino. A contagem de leucócitos exibiu uma média de $6643(\mathrm{DP} \pm 2067)$ células por $\mathrm{mm}^{3}$.

Todas as amostras submetidas à técnica da PCR tiveram 0 controle endógeno amplificado $(\mathrm{n}=53)$. 0 HTLV-1 foi detectado em 35 (66\%) amostras e o HTLV-2 em 18 (34\%) amostras, confirmando a infecção nestes indivíduos (Tabela 3).

\begin{tabular}{|c|c|c|c|c|c|}
\hline \multirow{2}{*}{$\begin{array}{l}\text { Faixa etária } \\
\text { (anos) }\end{array}$} & \multirow{2}{*}{$\begin{array}{l}\text { Amostras } \\
\text { (n) }\end{array}$} & \multicolumn{2}{|c|}{ Tipo viral } & \multicolumn{2}{|c|}{ Sexo } \\
\hline & & $1(\mathrm{n})$ & $2(\mathrm{n})$ & M (n) & $\mathrm{F}(\mathrm{n})$ \\
\hline $19 \mid-25$ & 6 & 2 & 4 & 5 & 1 \\
\hline $25 \mid-37$ & 12 & 8 & 4 & 10 & 2 \\
\hline $37 \mid-50$ & 26 & 19 & 7 & 17 & 9 \\
\hline$>50$ & 9 & 6 & 3 & 3 & 6 \\
\hline
\end{tabular}

Tabela 3 - Distribuição das amostras analisadas na PCR em relação ao tipo do HTLV infectante, sexo e faixa etária.

F: feminino; M: masculino; n: valor numérico referente ao item citado.

A quantificação proviral absoluta foi realizada, de acordo com a metodologia descrita, em todas as amostras deste estudo, exibindo uma média de carga proviral de 226 cópias de DNA proviral $/ \mathrm{mm}^{3}(\mathrm{DP} \pm 423)$, variando entre 0,02 e 1503 cópias/ $\mathrm{mm}^{3}$. Para análise da sensibilidade da PCR, na detecção dos HTLV, foram realizados três ensaios com amostras, em diferentes dias e placas. A flutuação de resultados, ora positivos, ora negativos na mesma amostra, nos três ensaios, foi interpretada como o limiar de sensibilidade que foi definido em 0,215 cópias de DNA por $\mathrm{mm}^{3}$ ou $\mu \mathrm{L}(\mathrm{DP} \pm 0,209)$ ou 215 cópias de DNA por $\mathrm{mL}(\mathrm{DP} \pm 209)$.

Além disto, para validar o método foi realizado um segundo ensaio com amostras em duplicata, cujo resultado foi avaliado pelo teste $t$ de Student, resultando em $\mathrm{p}=0,269$; o que mostra que o método é reprodutível e não se faz necessária à realização de réplicas durante procedimento de rotina.

\section{DISCUSSÃO}

A técnica da PCR vem sendo utilizada em diversos estudos de quantificação de carga proviral dos HTLV em células mononucleares de sangue periférico, tanto em indivíduos com manifestações clínicas associadas a este retrovírus, como em portadores assintomáticos ${ }^{25}$, os quais têm sido alvo destes estudos $^{131721}$.

A técnica da PCR em tempo real agrega algumas vantagens, dentre as quais: a utilização de sondas específicas, que atuam como sinalizadores moleculares, o que torna o ensaio altamente específico $^{10}$; reação em um só passo, o que elimina o processo pósPCR que diminui fontes de contaminações e erros ${ }^{6}{ }^{10}$; além do que, os valores de CT, gerados a partir do aumento do sinal fluorescente associado aos produtos de PCR, são mais sensíveis do que os valores end-point, pois as medidas são feitas durante a fase exponencial, onde os componentes da reação não são limitados ${ }^{11}$. 
Em nosso estudo, semelhante ao desenvolvido por Dehée $\operatorname{cols}^{6}$, a metodologia utilizada na PCR em tempo real amplifica as regiões não-homólogas do gene pol do HTLV-1 e do HTLV2 , atuando como alvos. Como controle endógeno, foi utilizado o gene celular da albumina. A amplificação do gene da albumina tem um importante papel como controle endógeno, permitindo uma quantificação proporcional. Tal gene é altamente conservado e atua de forma a normalizar variações causadas por diferenças na contagem de leucócitos, na extração de DNA e na presença de inibidores da $\mathrm{PCR}^{6}{ }^{18}$.

No estudo desenvolvido por Dehée cols ${ }^{6}$, células mononucleares do sangue periférico (PBMC) foram isoladas para quantificação da carga proviral do HTLV-1, em indivíduos portadores sintomáticos e assintomáticos. Para tanto, foram construídos plasmídeos, contendo uma porção do gene da albumina e outra porção do gene pol do HTLV-1, o que possibilitou a preparação de curvas padrão, feitas em diluições seriadas a partir da concentração estoque. Apesar de referida como uma curva padrão de fácil reprodução e preparação, a construção de plasmídeos torna a técnica inviável para rotina laboratorial.

Entretanto, nosso estudo demonstra que a extração de DNA proviral, a partir de leucócitos totais, assim como a contagem de leucócitos são suficientes para análise da carga proviral dos HTLV, em indivíduos infectados, tendo nosso grupo obtido resultados similares aos do autor acima referido $0^{6}$. Pode-se concluir, que a utilização da curva padrão é desnecessária, frente à presença do controle endógeno e da contagem de leucócitos para quantificação proviral absoluta.

De tal maneira, podemos afirmar que a técnica da PCR em tempo real, como proposta pelo nosso grupo, é uma ferramenta útil, simples, prática, sensível e reprodutível para quantificação da carga proviral do HTLV-1 e do HTLV-2, além de altamente específica e adequada, para detecção e discriminação da infecção por estes retrovírus.

\section{AGRADECIMENTOS}

Agradecemos à Fundação HEMOPA pela iniciativa no desenvolvimento deste trabalho, em especial à Dra. Luciana Maradei-Pereira.

\section{REFERÊNCIAS BIBLIOGRÁFICAS}

1. Brodine SK, Oldfield EC $3^{\text {rd }}$, Corwin AL, Thomas RJ, Ryan AB, Homlberg, J, Molgaard, CA, Golbeck AL, Ryden LA, Benenson AS. HTLV-I among U.S. marines stationed in a hyperendemic area: evidence for female-to-male sexual transmission. Journal of Acquired Immune Deficiency Syndrome and Human Retrovirology 5: 158-162, 1992.

2. Burke DS. Recombination in HIV: An important evolutionary strategy. Emergent Infectious Diseases 3: 253-258, 1997.

3. Busch MP, Stramer SL, Kleinman SH. Evolving applications of nucleic acid amplification assays for prevention of viral transmission by blood components and derivatives. In: Garratty G (ed) Applications of molecular biology to blood transfusion medicine. American Association of Blood Banks, Bethesda, p. 123-176, 1997.
4. Carrazone CFV, Brito AM, Gomes YMA importância de avaliação sorológica pré-transfusional em receptores de sangue. Revista Brasileira de Hematologia e Hemoterapia 26: 93-98, 2004.

5. Coffin JM. Retroviridae: The Viruses and their replication. In: Fiedls BN, Knipe DM, Howley PM, Chanock RM, Melnick JL, Monath TP, Roizman B, Straus SE (eds) Fundamental Virology. Lippincott Raven, Philadelphia, p. $763-843,1996$.

6. Dehée A, Cesaire R, Desire N, Lezin A, Bourdonne 0, Bera 0, Plumelle Y, Smadja D, Nicolas JC. Quantitation of HTLV-I proviral load by a TaqMan real-time PCR assay. Journal of Virological Methods 102: 37-51, 2002.

7. Egan JF, O’leary B, Lewis M, Mulcahy F, Shenny N, Hasegawa H, Fitzpatrick F, O'connor JJ, O'riondan J, Hall WW. High rate of human T-lymphotropic virus type IIa infection in HIV type 1 infected intravenous drug abusers in Ireland. AIDS Research and Human Retroviruses 15: 699-705, 1999.

8. Estes MC, Sevall JS. Multiplex PCR using real time PCR amplification for the rapid detection and quantitation of HTLV I or II. Molecular and Cellular Probes 17: 59-68, 2003.

9. Gessain A, Barin F, Vernant JC, Gout 0, Maurs L, Calender A, The G. Antibodies to human T-cell lymphotropic virus type-I in patients with tropical spastic paraparesis. Lancet 2: 407-410, 1985.

10. Ginzinger DG. Gene quantification using real-time quantitative PCR: An emerging technology hits the mainstream. Experimental Hematology 30: 503-512, 2002.

11. Giulietti A, Overbergh L, Vlackx D, Decallonne B, Bouillon R, Mathieu C. An Overview of Real-Time Quantitative PCR: Applications to Quantify Cytokine Gene Expression. Methods 25: 386-401, 2001.

12. Higuchi R, Fockler C, Dollinger G, Watson R. Kinetic PCR: Real time monitoring of DNA amplification reactions. Biotechnology 11: 1026-1030, 1993.

13. Hisada M, Okayama A, Shioiri S, Spiegelman DL, Stuver So, Mueller NE. Risk Factors for Adult T-Cell Leukemia Among Carriers of Human TLymphotropic Virus Type I. Blood 92: 3557-3561, 1998.

14. Holland PM, Abramson RD, Watson R, Gelfand D. Detection of especific polymerase chain reaction product by utilizing the $5^{\prime}$ to $3^{\prime}$ exonuclease activity of Thermus aquaticus DNA polymerase. Proceedings of the National Academy of Sciences USA 88: 7276-7280, 1991.

15. Ishak R, Ishak MOG, Azevedo VN, Santos DEM, Vallinoto, ACR, Saraiva JCP, Crescente JA, Hall WW. Detection of HTLV-IIa in blood donors in an urban area of the Amazon Region of Brazil (Belém, PA). Revista da Sociedade Brasileira de Medicina Tropical 31: 193-197, 1998.

16. Jaffe ES, Harris NL, Stein H, Vardiman JW (eds) World Health Organization Classification of Tumors. Pathology and Genetics of Tumors of Haematopoietic and Lymphoid Tissues. International Agency for Research on Cancer Press, Lyon, capítulo 7, p. 200-203, 2001.

17. Kira J, Koyanagi Y, Yamada T, Itoyama Y, Goto I, Yamamoto M, Sasaki H, Sasaki Y. Increased HTLV-I proviral DNA in the HTLV-I-associated myelopathy: a quantitative polymerase chain reaction study. Annals of Neurology 29: 194-201, 1991.

18. Machuca A, Soriano V. In vivo fluctuation of HTLV-I and HTLV-II Proviral Load in Patients Receiving Antiretroviral Drugs. Journal of Acquired Immune Deficiency Syndromes 24: 189-193, 2000a.

19. Machuca A, Tuset C, Soriano V, Caballero E, Aguilera A, Lejarazu RO, HTLV Spanish Study Group. Prevalence of HTLV infection in pregnant women in Spain. Sexual Transmitted Infections 76: 366-370, 2000b.

20. Madeleine MM, Wiktor SZ, Goeedert JJ, Manns A, Levine PH, Biggar RJ, Blattner WA. HTLV-I and HTLV-II world-wide distribution: reanalysis of 4.832 immunoblot results. International Journal of Cancer 54: 255-260, 1993.

21. Manns A, Miley WJ, Wilks RJ, Morgan OSt.C, Hanchard B, Wharfe G, Cranston B, Maloney E, Welles SL, Blattner WA, Waters D. Quantitative Proviral DNA and Antibody Levels in the Natural History of HTLV-I Infection. The Journal of Infectious Diseases 180: 1487-1493, 1999.

22. Manns A, Wilks RJ, Murphy EL, Haynes G, Figueroa JP, Barnett M, Hanchard B, Blattner WA. A prospective study of transmission by transmission of 
HTLV-I and risk factors associated with seroconversion. International Journal of Cancer 51: 886-891, 1992.

23. Mochizuki M, Watanabe T, Yamaguchi K, Yoshimura K. HTLV-I uveitis: a distinct clinical entity caused by HTLV-I. Japanese Journal of Cancer Research 83: 236-239, 1992.

24. Montanheiro PA, Penalva de Oliveira AC, Posada-Vergara MP, Milagres C, Tauil C, Marchiori PE, Duarte AJS, Casseb J. Human T-cell lymphotropic virus type I (HTLV-I) proviral DNA viral load among asymptomatic patients and patients with HTLV-I-associated myelopathy/tropical spastic paraparesis. Brazilian Journal of Medical and Biological Research 38: 1643-1647, 2005

25. Nagai M, Usuku K, Matsumoto W, Kodama D, Takenouchi N, Moritoyo T, Hashiguchi S, Ichinose M, Bangham CRM, Izumo S, Osame M. Analysis of HTLV-I proviral load in $202 \mathrm{HAM} / \mathrm{TSP}$ patients and 243 asymptomatic HTLVI carriers: high proviral load strongly predisposes to HAM/TSP. Journal of Neurovirology 4: 586-593, 1998.

26. Nakagawa M, Izumo S, Ijichi S, Kubota H, Arimura K, Kawabata M, Osame M. HTLV-I association myelopathy: analisis of 213 patients based on clinical features and laboratory findings. Journal of Neurovirology 1: 50-61, 1995.

27. Ribeiro-Lenzi ME, Araújo AQ, Leite AC, Neves ES, Maya TC, Andrada-Serpa MJ. Dermatite infecciosa associada ao HTLV-I: relato de caso. Anais Brasileiros de Dermatologia 71: 115-118, 1996.
28. Saito S, Ruruki K, Ando Y, Tanigawa T, Kakimoto K, Morivama I, Ichijo M Identification of HTLV-I sequence in cord blood mononuclear cells of neonates Born to HTLV-I antigen/antibody-positive mothers by polimerase reaction. Japanese Journal of Cancer Research 81: 890-895, 1990.

29. Schreiber GB, Busch MP, Kleinman SH, Korelitz JJ. The risk of transfusiontransmitted viral infections. Retrovirus Epidemiology Donor Study. The New England Journal of Medicine 334: 1685-1690, 1996.

30. Segurado AA, Malaque CM, Sumita LM, Pannuti CS, Lal RB. Laboratory characterization of human T-cell lymphotropic virus type I (HTLV-I) and II (HTLV-II) infection in blood donors from São Paulo, Brazil. American Journal of Tropical Medicine and Hygiene 57: 142-148, 1997.

31. Takatsuki K, Matsuoka M, Yamaguchi K. Adult T-cell Leukemia in Japan. Journal of Acquired Immune Deficiency Syndromes and Human Retrovirology 13, S15-S19, 1996.

32. The G, Bomford R. An HTLV-I vaccine: why, how, for whom? AIDS Research Human Retroviruses 9: 381-386, 1993.

33. Vet JAM, Majithia RA, Marras, SAE, Tyagi S, Dube S, Poiesz BJ, Kramer FR Multiplex detection of four pathogenic retroviruses using molecular beacons. Proceedings of the National Academy of Science 96: 6394-6399, 1999.

34. Yoshioka A, Hriose G, Ueda Y, Nishimura Y, Sakai K. Neuropthological studies of the spinal cord in early stage HTLV-I association myelopathy (HAM). Journal of Neurology, Neurosurgery and Psychiatry 56: 1004-1007, 1993. 